\title{
HUBUNGAN KEIKUTSERTAAN IBU HAMIL PADA KELAS IBU DENGAN INISIASI MENYUSU DINI DAN PEMBERIAN ASI EKSKLUSIF
}

\author{
Giari Rahmilasari \\ Program Studi Sarjana Kebidanan Fakultas Ilmu Kesehatan \\ Universitas 'Aisyiyah Bandung \\ rahmilasari.giari@gmail.com
}

\begin{abstract}
ABSTRAK
Inisiasi Menyusu Dini (IMD) dan pemberian ASI eksklusif dipercaya sebagai cara untuk menurunkan kematian neonatus. IMD dan ASI Eksklusif menjadi salah satu materi penting yang disampaikan dalam Kelas ibu hamil. KIH juga merupakan usaha yang dilanjutkan untuk mencapai target SDGs (Sustainable Development Goals). Tujuan penelitian ini untuk mengetahui hubungan keikutsertaan ibu dalam kelas ibu hamil dengan pelaksanaan IMD dan pemberian ASI Eksklusif. Manfaat secara langsung yaitu memberikan informasi mengenai IMD dan ASI Eksklusif pada subjek penelitian, dan menjadi data dasar bagi bidan wilayah sekitar dalam memberikan peningkatan pelayanan pada ibu hamil, khususnya pada pemberian pelayanan kelas ibu hamil. Data diambil dari enam desa yang berada di wilayah kerja Puskesmas Bojongsoang kabupatem Bandung, yaitu Cipagalo, Bojongsoang, Bojongsari, Lengkong, Buahbatu, dan Tegalluar. Penelitian ini menggunakan rancangan cross sectional study, pada ibu yang memiliki bayi 0-5 tahun. Hasil penelitian menunjukkan bahwa ibu yang mengikuti kelas ibu hamil memiliki rerata pelaksanaan IMD yang lebih rendah $(\mathrm{M}=0,5489)$. Pada pemberian ASI Eksklusif data menunjukkan bahwa ibu yang mengikuti kelas ibu hamil memberikan ASI eksklusif jauh lebih tinggi ( $M=0,7191)$, dengan perbedaan yang sangat signifikan $(t=-2,924, p<0,01)$. Maka dalam penelitian ini disimpulkan bahwa pelaksanaan kelas ibu berhubungan dengan pemberian ASI Eksklusif.
\end{abstract}

Kata kunci : ASI eksklusif, inisiasi menyusu dini, kelas ibu hamil

\begin{abstract}
Early Breastfeeding Initiation (EBI) and exclusive breastfeeding to newborns believe in reducing neonatal mortality. EBI and exclusive breastfeeding are some of the substances in the class for pregnant women. This class is also an ongoing effort to achieve the SDGs (Sustainable Development Goal's) targets.This study aimed to determine the relationship between mother's participation in the class of pregnant women with the implementation of EBI and exclusive breastfeeding. The direct benefits for the subject are providing information about EBI and exclusive breastfeeding and becoming primary data for local midwives to improved services, especially in classes for pregnant women. Data were taken from six villages located in the working area of the Puskesmas Bojongsoang Bandung district, namely Cipagalo, Bojongsoang, Bojongsari, Lengkong, Buahbatu, and Tegalluar. This study uses a cross-sectional study design on mothers who have babies 0-5 years. The results showed that the mothers who took the class for pregnant women had a lower average EBI implementation $(M=0.5489)$. On exclusive breastfeeding, the data showed that mothers who participated in the class of pregnant women gave exclusive breastfeeding much higher $(M=0.7191)$, with a very significant difference $(t=-2.924$, $p<0.01)$. Thus, this study concludes that the implementation of the mother's class is related to exclusive breastfeeding.
\end{abstract}

Keyword: early breastfeeding initiation, exclusive breastfeeding, pregnancy class 


\section{PENDAHULUAN}

Latar belakang penelitian ini adalah munculnya masalah di masyarakat berupa kelemahan pada sistem penyuluhan yang biasa digunakan pada saat memeriksakan kehamilan atau posyandu. Kegiatan penyuluhan yang konvensional memiliki beberapa kelemahan yaitu (a) Pengetahuan yang diperoleh hanya terbatas pada masalah kesehatan yang dialami saat konsultasi (b) Penyuluhan yang diberikan tidak terkoordinir sehingga ilmu yang diberikan kepada ibu hanyalah pengetahuan yang dimiliki oleh petugas saja (c) Tidak ada rencana kerja sehingga tidak ada pemantauan atau pembinaan secara lintas sektor dan lintas program (d) Pelaksanaan penyuluhan tidak terjadwal dan tidak berkesinambungan. Beberapa masalah diatas, dicoba untuk dapat diatasi dengan diadakannya kelas ibu hamil yang berpanduang kepada buku KIA yang telah disusun dan diterbitkan oleh Depkes RI tahun 2009. Namun seiring berjalannya waktu, kelas ibu yang telah dilaksanakan setelah dilakukan evaluasi dalam penelitian Fuada \& Setyawati (2015), direkomendasikan untuk merubah pola dan dilakukan beberapa upaya perbaikan kinerja program kelas ibu hamil, yaitu memperhatikan kondisi kinerja program kelas ibu hamil (memperhatikan kondisi kinerja fasilitator tingkat puskesmas, dinas, kabupaten dan provinsi, meningkatkan profesionalisme fasilitator, mempromosikan kepada masyarakat luas tentang kelas ibu hamil melalui teknologi informasi, dan mengajak stakeholder untuk terlibat pelaksanaan kelas ibu hamil. Saat penelitian tersebut berlangsung, kelas ibu hamil hanya dilakukan di puskesmas, dengan melakukan pelatihan pada bidan puskesmas untuk menjadi fasilitator kelas ibu hamil. Penelitian lain tentang kelas ibu hamil di wilayah kerja Puskesmas Tawangrejo, Kartoharjo, Madiun tahun 2016 mengungkapkan, terdapat hubungan keikutsertaan kelas ibu hamil dengan pemberian ASI eksklusif. Ibu yang mengikuti kelas ibu hamil berpeluang 55 kali memberikan ASI eksklusif. Namun belum ada penelitian yang melihat hubungan keikutsertaan pada kelas ibu hamil dengan pelaksanaan IMD (Y. Utami \& Westri, 2016).

Peraturan Pemerintah yaitu No.33 Tahun 2012, mencatat bahwa tanggung jawab pemerintah dalam pemberian ASI Eksklusif, yang meliputi pemerintah provinsi, pemerintah daerah kabupaten/kota. Peraturan Pemerintah tersebut terdiri dari 43 pasal yang mengatur berbagai hal pendukung tercapainya keberhasilan ASI Eksklusif dan IMD di Indonesia. Secara definisi disebutkan bahwa ASI yang diberikan kepada bayi sejak dilahirkan selama enam bulan, tanpa menambahkan dan/atau mengganti dengan makanan atau minuman lain (kecuali obat, vitamin, dan mineral) PPRI, (2012), sedangkan IMD adalah bayi menyusu sendiri segera setelah lahir R. Utami (2008) yang berperan sebagai programyang dapat menurunkan Angka Kematian Bayi (AKB) sekurang-kurangnya 30.000 bayi di Indonesia. 40\% kematian bayi di bawah 28 hari dapat diselamatkan sebanyak 22\% dengan Inisiasi Menyusu Dini (WHO, 2010). Sejalan dengan pernyataan WHO tersebut, penelitian yang dilakukan oleh Smith Emily R, dan kawankawan menyatakan bahwa dibandingkan bayi yang memulai menyusui 1 jam setelah lahir, bayi yang mulai menyusui 2-23 jam setelah lahir, memiliki risiko kematian neonatal 33\% lebih besar, dan bayi yang menyusui dimulai 24 jam setelah lahir memiliki risiko kematian neonatal 2,19 kali lipat lebih besar (Smith et al., 2017).

Riskesdas tahun 2013 mencatat proses mulai menyusu atau IMD mengalami kenaikan dari $29,3 \%$ pada tahun 2010 menjadi 34,5\% pada tahun 2013, berarti terdapat kenaikan 5,2\%. Cakupan IMD nasional sebesar 34,5\% 
dan terdapat 18 provinsi yang cakupannya di bawah angka nasional. Provinsi Jawa Barat termasuk provinsi dengan cakupan IMD di atas angka nasional, yaitu 35,7\%. Bidan dan tenaga kesehatan lainnya tetap harus melakukan upaya agar dapat meningkatkan nilai cakupannya, salah satunya dengan cara melakukan penyuluhan (Riskesdas, 2013).

Pengetahuan dan sikap tentang IMD telah dilakukan oleh beberapa peneliti terdahulu, dengan hasil yang menunjukkan bahwa masih terdapat pengetahuan ibu yang kurang tentang IMD bahkan terdapat beberapa yang memiliki sikap negatif terhadap IMD (Hartatik, 2012). IMD dan ASI Eksklusif juga memiliki hubungan yang bermakna dengan kejadian stunting, Anak yang tidak mendapatkan IMD memiliki kemungkinan 2,63 kali lebih tinggi mengalami kejadian stunting, selain itu anak yang tidak mendapatkan ASI Eksklusif memiliki risiko mengalami kejadian stunting 7,86 kali lebih tinggi dibandingkan anak yang mendapatkan ASI Eksklusif (Permadi et al., 2017).

Informasi tentang IMDkepadamasyarakat diharapkan sudah menyebar luas, namun pada kenyataannya, penyebarluasan informasi tentang IMD tidak segencar tentang pemberian ASI eksklusif selama 6 bulan yang telah dimulai sejak lama, padahal keberhasilan pemberian ASI eksklusif selama 6 bulan memiliki kesempatan delapan kali lebih berhasil jika diawali dengan IMD (Sutomo \& yanti Anggraini, 2010). Penyebaran informasi ini dirasakan perlu lebih ditingkatkan pada ibu trimester III, karena pada usia kehamilan ini ibu mulai mempersiapkan persalinannya, dan diharapkan setelah terpapar informasi tentang IMD, maka ibu dan bayi mendapatkan haknya untuk dapat melakukan IMD saat persalinan nanti.

Indikator bina kesehatan ibu salah satunya adalah persentase puskesmas yang melaksanakan kelas Ibu hamil, karena melalui kelas ibu hamil diharapkan terjadi peningkatan pengetahuan, perubahan sikap dan perilaku ibu dalam hal kehamilan, perubahan tubuh dan keluhan selama kehamilan, perawatan kehamilan, persalinan, perawatan nifas, KB pasca persalinan, perawatan bayi baru lahir, mitos/kepercayaan/adat istiadat setempat, penyakit menular, dan akte kelahiran (Ditjen Bina Gizi dan KIA Kementrian Kesehatan, 2015)

Target persentase puskesmas yang melaksanakan kelas ibu hamil, dari tahun 2015 hingga 2019 berturut turut adalah 78\%, 84\%, $84 \%$, 87\%, dan $90 \%$ pada tahun 2019. Secara nasional, capaian yang berhasil didapatkan Indonesia dalam pelaksanaan kelas ibu hamil adalah $86,92 \%$, yang artinya semua provinsi sudah memiliki trainer pelatihan kelas ibu bagi seluruh provinsi, dan telah memiliki dukungan dana untuk melaksanakan pengembangan kelas ibu melalui pelatihan fasilitator tahun 2015 dan pengadaan paket kelas ibu hamil (Ditjen Bina Gizi dan KIA Kementrian Kesehatan, 2015).

Kabupaten Bandung telah memiliki 13 Puskesmas Mampu PONED, berdasarkan data Laporan Tahunan Kabupaten Bandung, Tahun 2012. Pendirian PONED tersebut, sebagai salah satu usaha pemerintah dan pemerintah daerah mengatasi angka kematian di Provinsi Jawa Barat yang masih tergolong tinggi, yaitu 765 kasus kematian dari total 5.019 kasus (Laporan rutin Program Kesehatan Dinas Kesehatan Provinsi Jawa Barat, 2013). Angka tersebut menyebabkan Jawa Barat menjadi penyumbang sekitar 50\% jumlah kematian Ibu di Indonesia. Kabupaten Bandung pada tahun 2013 memiliki jumlah kematian ibu sebesar 48 kasus, yang artinya menyumbang sekitar 6,27\% dari 765 kasus pada tahun 2013 (Dinkes Kabupaten Bandung, 2015). Penurunan Angka Kematian Bayi (AKB) di kabupaten Bandung juga tergolong tidak 
signifikan, yaitu 33,64 pada tahun 2015, dan target penurunan AKI di tahun 2016 menjadi 33,62 (Pemkab Bandung, 2016)

Tujuan penelitian ini adalah untuk mengetahui hubungan antara keikutsertaan ibu dalam kelas ibu hamil dengan pelaksanaan Inisiasi Menyusu Dini pada saat persalinan dan pemberian asi eksklusif pada bayi yang dilahirkan.

Manfaat penelitian ini adalah dapat secara langsung memberikan informasi pada ibu khususnya tentang IMD dan ASI Eksklusif. Penelitian ini juga dapat dimanfaatkan sebagai bahan untuk meningkatkan pelayanan khususnya pada kelas ibu hamil.

\section{METODOLOGI}

Bayi yang diberi kesempatan untuk inisiasi menyusu dini lebih berhasil menyusu secara eksklusif, yang dampak jangka panjangnya adalah menurunkan Angka Kesakitan dan Kematian Bayi.

Variabel bebas pada penelitian ini adalah yaitu keikutsertaan ibu pada kelas Ibu hamil, dan variabel tergantungnya adalah IMD pada saat persalinan dan pemberian ASI Eksklusif. Jenis penelitian yang digunakan oleh peneliti adalah analitik melalui pendekatan Cross-Sectional. Penelitian ini dilakukan hanya sekali untuk mengetahui hubungan keikutsertaan ibu pada kelas ibu hamil dengan pelaksanaan IMD pada saat persalinan dan pemberian ASI Eksklusif.

Populasi dalam penelitian ini adalah seluruh ibu yang memiliki bayi diatas 6 bulan di wilayah kerja PONED Kabupaten Bandung yang tercatat dalam buku register pada bulan Januari Desember 2017.

Karena jumlah populasi tidak diketahui, maka penelitian ini akan menggunakan data penelitian sebelumnya, yaitu dengan rumus sebagai berikut:

$$
n=\frac{4 p q}{d^{2}}
$$

Keterangan:

$\mathrm{n}=$ jumlah sampel minimal yang diperlukan

$\mathrm{p}=$ proporsi dari penelitian sebelumnya

$\mathrm{q}=1-\mathrm{p}$

$\mathrm{d}=$ batas error

Pada penelitian sebelumnya, diketahui bahwa proporsi ibu yang memberikan ASI Eksklusif adalah 42,9\%, dan yang ikut serta dalam kelas ibu hamil adalah 40,5\%, proporsi yang akan diambil adalah keikutsertaan ibu dalam kelas ibu hamil, yaitu 40,5\%, dengan limit error (d) ditetapkan 0,05 dan Nilai Alfa $(\alpha)$ adalah 0,05. Maka, penelitian ini membutuhkan sampel:

$$
n=\frac{1,96^{2} \cdot 0,405 \cdot 0,6735}{0,05^{2}}
$$

$\mathrm{n}=419,145$ dibulatkan menjadi 419 responden. Namun partisipan dalam penelitian ini adalah 499 orang.

\section{HASIL}

Distribusi Frekuensi usia responden dari 499 orang, terdapat pada Diagram 1, yaitu dengan rentang usia terbanyak terdapat di rentang usia produktif (25-29 tahun) yaitu sebanyak 132 orang atau setara dengan $26,45 \%$ dan yang paling sedikit yaitu pada usia berisiko (45-49 tahun) yaitu sembilan orang $(1,80 \%)$ dan pada rentang usia 15-19 tahun berjumlah 11 orang $(2,20 \%)$. 


\section{Diagram 1. Distribusi Frekuensi Responden berdasarkan Usia}

\section{Distribusi Frekuensi Usia Responden}

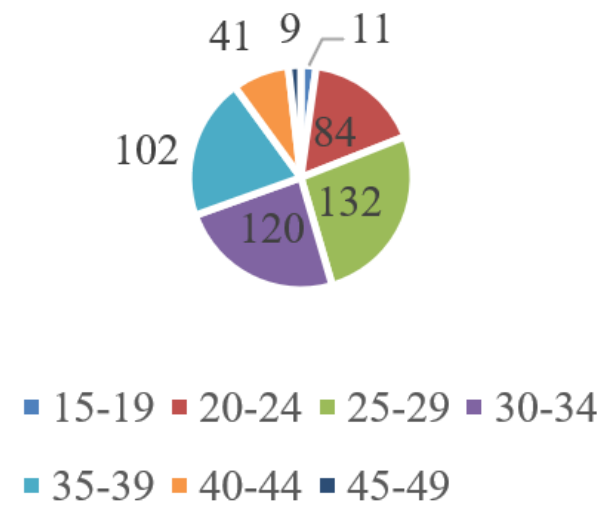

Pada Diagram 2 ditampilkan distribusi $38 \%$ atau sebanyak 187 orang, dan yang paling frekuensi pendidikan responden pada penelitian sedikit adalah yang mengenyam Pendidikan ini, dengan hasil sebagian besar responden tinggi, yaitu 9\% (46 orang).

memiliki Pendidikan setingkat SMA/SLTA yaitu

\section{Diagram 2. Distribusi Frekuensi Responden berdasarkan Tingkat Pendidikan}

\section{Distribusi Frekuensi Usia Responden}

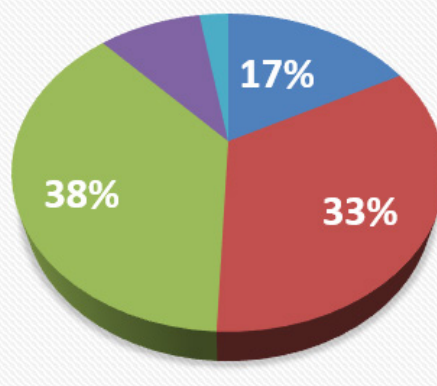

Sebagian besar responden tidak mengikuti kelas ibu hamil yang programnya dilaksanakan oleh bidan desa, yaitu sebesar 53\% (264 orang) dan yang mengikuti kelas ibu hamil 47\% (235 $\square \mathrm{SD}$

\section{- SMP/SLTP}

- SMA/SLTA

- Perguruan Tinggi

- Tidak menjawab

Diagram 3. Distribusi Frekuensi Responden berdasarkan Keikutsertaan Responden pada Kelas Ibu Hamil

\section{Distribusi Frekuensi Keikutsertaan Ibu pada Kelas Ibu Hamil}

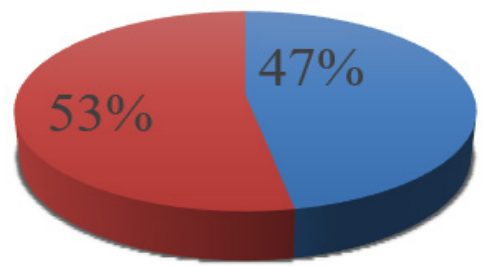

orang). Hasil distribusi frekuensi responden berdasarkan keikutsertaan pada kelas ibu hamil ditunjukan pada diagram 3 . (1) 
Pada uji beda (terdapat pada Tabel 1), didapatkan hasil bahwa terdapat perbedaan yang sangat signifikan pada pelaksanaan IMD pada kelompok yang ikut kelas ibu hamil dengan yang tidak ikut dengan nilai $\mathrm{t}=3,079$ dan $\mathrm{p}=<0,01$. Namun data menunjukkan ibu yang mengikuti kelas ibu hamil memiliki rerata yang lebih rendah dalam pelaksanaan IMD $(\mathrm{M}=0,5489)$.

Tabel 1. Rerata Keikutsertaan Kelas Ibu Hamil pada Ibu yang Melakukan IMD

\begin{tabular}{llrrrr}
\hline & Kelas Hamil & N & Mean & Std. Deviation & $\begin{array}{c}\text { Std. Error } \\
\text { Mean }\end{array}$ \\
\hline IMD & Tidak ikut & 267 & .6816 & .46671 & .02856 \\
& Ikut & 235 & .5489 & .49866 & .03253 \\
\hline
\end{tabular}

Pada tabel 2 dapat terlihat bahwa terdapat perbedaan yang sangat signifikan pada pelaksanaan IMD pada kelompok yang ikut kelas hamil dan tidak ikut kelas hamil $(\mathrm{t}=3,079$, $\mathrm{p}<0,01)$. Data menunjukkan bahwa kelas hamil memiliki rerata pelaksanaan IMD yang lebih rendah $(M=0,5489)$ dibandingkan IMD pada ibu yang tidak ikut kelas hamil $(\mathrm{M}=0,6816)$.

Tabel 2. Perbedaan Keikutsertaan Kelas Ibu Hamil pada Ibu yang Melakukan IMD

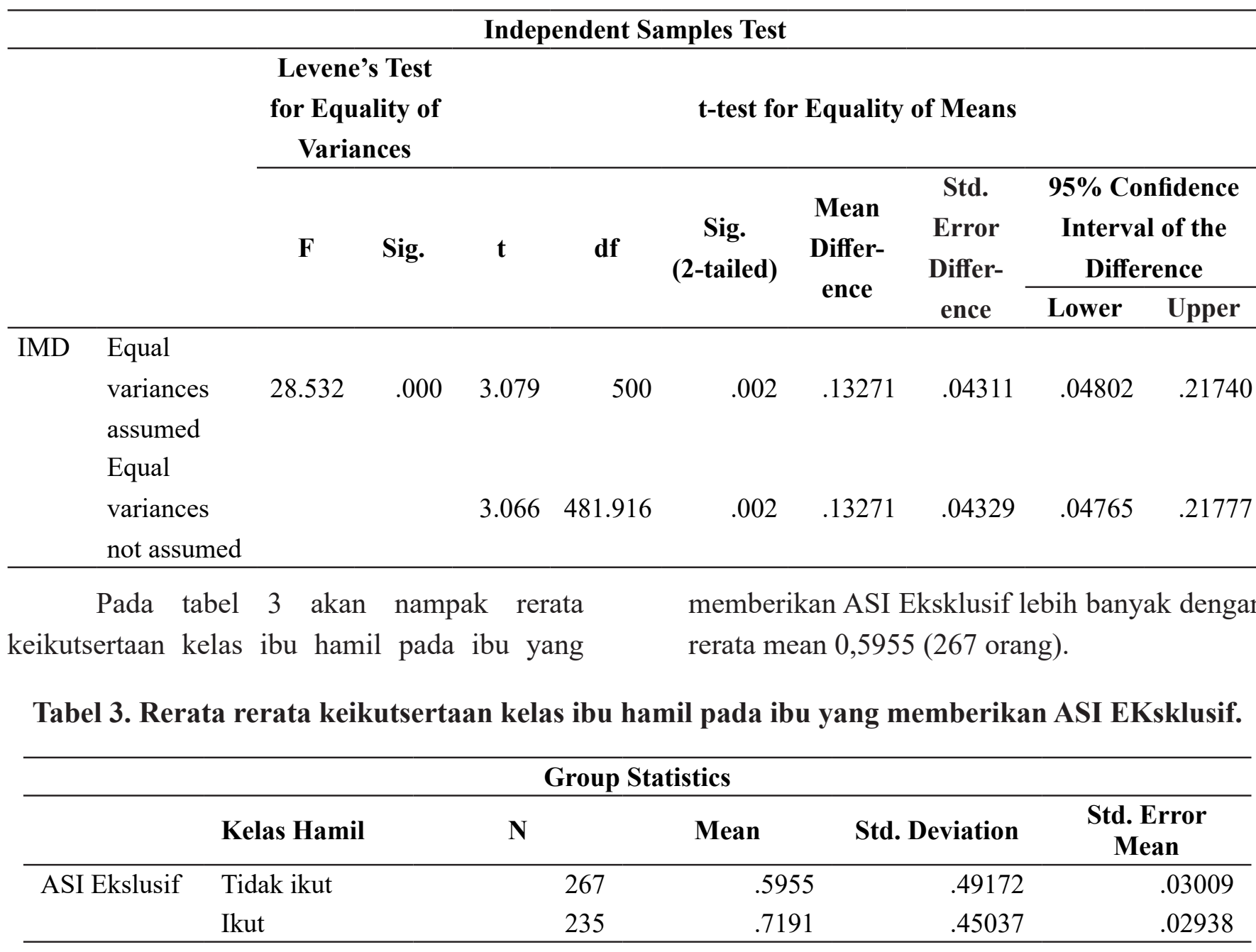


Hasil uji beda pada pemberian ASI Eksklusif juga terdapat pemberian yang sangat signifikan pada kelompok yang ikut kelas ibu hamil. (Tabel 4). Hasil uji hubungan pada kelas ibu hamil dengan pemberian ASI Eksklusif, didapatkan hasil bahwa terdapat hubungan yang signifikan antara keikutsertaan kelas hamil dan pemberian ASI Eksklusif, dan pelaksanaan IMD (Tabel 5 dan Tabel 6).

Tabel 4. Perbedaan Keikutsertaan Kelas Ibu Hamil pada Ibu yang Memberikan ASI Eksklusif

\begin{tabular}{|c|c|c|c|c|c|c|c|c|c|c|}
\hline \multicolumn{11}{|c|}{ Independent Samples Test } \\
\hline & & \multicolumn{2}{|c|}{$\begin{array}{c}\text { Levene's Test } \\
\text { for Equality of } \\
\text { Variances } \\
\end{array}$} & \multicolumn{7}{|c|}{ t-test for Equality of Means } \\
\hline & & \multirow[t]{2}{*}{$\mathbf{F}$} & \multirow[t]{2}{*}{ Sig. } & \multirow[t]{2}{*}{$\mathbf{t}$} & \multirow[t]{2}{*}{ df } & \multirow[t]{2}{*}{$\begin{array}{c}\text { Sig. } \\
\text { (2-tailed) }\end{array}$} & \multirow[t]{2}{*}{$\begin{array}{c}\text { Mean } \\
\text { Differ- } \\
\text { ence }\end{array}$} & \multirow{2}{*}{$\begin{array}{c}\text { Std. } \\
\text { Error } \\
\text { Differ- } \\
\text { ence }\end{array}$} & \multicolumn{2}{|c|}{$\begin{array}{c}\text { 95\% Confidence } \\
\text { Interval of the } \\
\text { Difference } \\
\end{array}$} \\
\hline & & & & & & & & & Lower & Upper \\
\hline $\begin{array}{l}\text { ASI } \\
\text { Eksk- } \\
\text { lusif }\end{array}$ & $\begin{array}{l}\text { Equal } \\
\text { variances } \\
\text { assumed }\end{array}$ & 33.003 & .000 & -2.924 & 500 & .004 & -.12364 & .04229 & -.20673 & -.04055 \\
\hline & $\begin{array}{l}\text { Equal } \\
\text { variances } \\
\text { not assumed }\end{array}$ & & & -2.940 & 499.197 & .003 & -.12364 & .04206 & -.20627 & -.04102 \\
\hline
\end{tabular}

Pada tabel 4 dapat diketahui bahwa pemberian ASI Eksklusif juga terdapat perbedaan yang sangat signifikan pada kelompok yang ikut kelas hamil dan tidak ikut $(\mathrm{t}=-2,924, \mathrm{p}<0,01)$. data menunjukkan bahwa penerapan pemberian ASI dikelas hamil jauh lebih tinggi (Mean=0,7191) dibandingkan dengan yang tidak ikut kelas hamil (Mean=0,5955).

Tabel 5. Hubungan Pelaksanaan Kelas Ibu Hamil dengan pemberian ASI Eksklusif

\begin{tabular}{ccccc}
\hline \multirow{2}{*}{ Kelas Ibu } & \multicolumn{2}{c}{ ASI Eksklusif } & \multirow{2}{*}{ Total } & \multirow{2}{*}{ p-value } \\
\cline { 2 - 3 } & Ya & Tidak & & \\
\hline Ikut & 169 & 66 & 235 & \\
& $33,7 \%$ & $13,1 \%$ & $100 \%$ & 0,004 \\
Tidak Ikut & 159 & 108 & 267 & \\
& $31,7 \%$ & $21,5 \%$ & $100 \%$ & \\
\hline
\end{tabular}

Hasil analisis bivariate dengan menggunakan Chi Square yang tampak pada tabel 5 menunjukkan keikutsertaan ibu pada kelas ibu hamil dalam penelitian ini memiliki hubungan yang signifikan $(\mathrm{p}<0,5)$ terhadap pemberian ASI Eksklusif, dengan nilai signifikansi 0,004. 
Tabel 6. Hubungan Pelaksanaan Kelas Ibu Hamil dengan pelaksanaan IMD

\begin{tabular}{cccccc}
\hline \multirow{2}{*}{ Kelas Ibu } & \multicolumn{2}{c}{ IMD } & Total & p-value \\
\cline { 2 - 3 } & Ya & Tidak & & \\
\hline Ikut & 129 & 106 & 235 & \\
& $25,7 \%$ & $21,1 \%$ & $100 \%$ & 0,002 \\
Tidak Ikut & 182 & 85 & 267 & \\
& $36,3 \%$ & $16,9 \%$ & $100 \%$ & \\
\hline
\end{tabular}

Pada tabel 6 nampak bahwa keikutsertaan ibu pada kelas ibu hamil dalam penelitian ini memiliki hubungan yang signifikan $(p<0,5)$ terhadap pemberian IMD, dengan nilai signifikansi 0,002

\section{PEMBAHASAN}

Hal yang cukup menggembirakan bahwa ibu yang ikut serta sebagai responden berada di rentang usia yang dianggap paling matang usia reproduksinya, sehingga diharapkan komplikasi yang terjadi dapat di minimalisir. Namun masih ada sebagian kecil responden yang hamil pada usia remaja (15-19 tahun) yang merupakan kategori kehamilan risiko tinggi (Cunningham et al., 2014).

Penelitian ini juga menemukan bahwa 38\% ibu memiliki pendidikan SMA sederajat. Hal ini cukup baik karena faktor pendidikan ibu berpengaruh pada kesehatan anak. Ibu yang berpendidikan cenderung terlibat mencari tahu lebih banyak dalam informasi kesehatan. Sebuah jurnal juga menjelaskan bahwa di beberapa negara, pendidikan ibu memiliki dampak yang signifikan secara statistik terhadap kematian bayi, dan bahkan sangat terlihat di lebih banyak negara untuk status imunisasi anak-anak (Desai \& Alva, 1998).

Kelas ibu yang didalan oleh bidan desa hanya diikuti oleh $47 \%$ ibu hamill yang berada di wilayah kerja Puskesmas Bojongsoang, Kabupaten Bandung. Hal ini terjadi dimungkinkan karena ibu sebagian besar ada di rentang usia produktif, yang sebagiannya adalah bekerja, ataupun ibu rumah tangga dengan anak lain. Pelaksanaan kelas ibu umumnya terjadwal sesuai dengan jadwal posyandu, sehingga tidak ada fleksibilitas waktu bagi ibu yang bekerja atau memiliki anak lain. Sehingga hal ini sejalan dengan penelitian yang dilakukan untuk menelaah pelaksanaan kelas ibu hamil di Indonesia yang mendapatkan hasil bahwa selama ini program kelas ibu hamil (KIH) yang menunjang program KIA dengan pelaksana/fasilitatornya adalah bidan desa, dirasakan belum maksimal. Masyarakat masih banyak yang belum mengenal KIH. Berbagai upaya yang dapat dilakukan yaitu dengan meningkatan kinerja program KIH baik di tingkat puskesmas, tingkat kesehatan kabupaten dan provinsi, dan meningkatkan profesionalitas fasilitator. Perubahan strategi juga dirasakan perlu, direkomendasikan untuk dapat mempromosikan kepada masyarakat luas tentang pelaksanaan $\mathrm{KIH}$ dan mengajak seluruh stakeholder untuk terlibat $\mathrm{KIH}$, serta perlunya promosi di social media (Fuada \& Setyawati, 2015).

Hasil penelitian ini mendapatkan rerata ibu yang mengikuti kelas ibu hamil justru lebih rendah dalam pelaksanaan IMD, dan terdapat hubungan yang negatif antara pelaksanaan $\mathrm{KIH}$ dengan pelaksanaan IMD. Hal ini mungkin saja terjadi, karena pengetahuan tidak selalu sejalan dengan perbuatan. Lawrence Green (1980) menyatakan bahwa sikap masih merupakan perilaku tertutup dan belum tentu menjadi perilaku terbuka (Lawrence, 1980).

Faktor dominan yang berhubungan dengan pemberian ASI satu jam pertama adalah 
tenaga periksa hamil. Faktor lain adalah adalah daerah tempat tinggal, kehamilan diinginkan, tenaga periksa hamil, penolong persalinan, akses terhadap radio, dan berat lahir. Terdapat interaksi antara daerah dengan tenaga periksa, kehamilan diinginkan dengan tenaga periksa, dan berat lahir dengan penolong persalinan (Rahardjo, 2006).

Hasil penelitian pada pemberian ASI Eksklusif menunjukkan bahwa ibu yang mengikuti kelas ibu hamil menunjukkan angka yang lebih tinggi dalam penerapan ASI Eksklusif dan memiliki hubungan yang kuat antara keikutsertaan ibu pada kelas ibu hamil dengan pemberian ASI Eksklusif. Hal dapat juga disebabkan faktor ibu yang setara SMA pada penelitian ini lebih banyak pada responden, sehingga pengetahuan tentang ASI Eksklusif dapat diterima dengan baik. Hal ini sejalan dengan hasil penelitian di Kota Bandung yang menyebutkan bahwa keberhasilan ibu menyusui sangat dipengaruhi oleh dukungan suami sebagai orang yang paling dekat dengan ibu, selain dengan tenaga kesehatan yang membantu pada saat persalinan (Handayani et al., n.d.). Penelitian lain di Jepang juga menunjukkan bahwa pemberian ASI Eksklusif tidak hanya berkaitan dengan faktor medis, namun juga berkaitan dengan faktor sosial, sehingga sangat dibutuhkan dukungan sosial untuk pengasuhan anak termasuk partisipasi ayah dalam pengasuhan Kaneko et al. (2006) Informasi tentang IMD kepada masyarakat diharapkan sudah menyebar luas, namun pada kenyataannya, penyebarluasan informasi tentang IMD tidak segencar tentang pemberian ASI eksklusif selama 6 bulan yang telah dimulai sejak lama, padahal keberhasilan pemberian ASI eksklusif selama 6 bulan memiliki kesempatan delapan kali lebih berhasil jika diawali dengan IMD 98.

\section{SIMPULAN DAN SARAN}

Penelitian ini mendapatkan kesimpulan bahwa kelas ibu hamil sangat berhubungan dengan pelaksanaan IMD dan pemberian ASI Eksklusif. Pelaksanaan Inisiasi Menyusu Dini (IMD), perlu dilakukan dengan kerjasama seluruh lingkungan ibu, seperti kualitas bidan yang memberikan penjelasan pada kelas ibu, dukungan suami, dan bidan pada seluruh wilayah kerja yang menerapkan IMD pada seluruh persalinannya.

Diharapkan dapat dilakukan kerjasama lintas sektor untuk keberhasilan pelaksanaan IMD dan ASI Eksklusif, yaitu dengan pelaksanaan kelas ibu hamil yang rutin, fasilitator dengan kualitas yang baik, dan pelaksanaannya bisa dilakukan juga di praktek bidan mandiri, bukan hanya oleh bidan desa. Pelaksanaan kelas ibu hamil juga dianjurkan untuk selalu dihadiri pendamping yang akan mendampingi persalinan kelak, misalnya suami atau keluarga ibu hamil sebagai bentuk dukungan kepada ibu untuk keberhasilan pelaksanaan IMD dan ASI Eksklusif. Terutama pengetahuan pendamping persalinan, dan tenaga kesehatan penolong persalinan untuk lebih dapat dikuatkan tentang Inisiasi Menyusu Dini.

\section{DAFTAR PUSTAKA}

Cunningham, F. G., Leveno, K. J., \& Bloom, S. L. (2014). William Obstetri 24th. Jakarta: EGC.

Desai, S., \& Alva, S. (1998). Maternal education and child health: Is there a strong causal relationship? Demography, 35(1), 71-81.

Dinkes Kabupaten Bandung. (2015). Laporan tahunan 2014 Dinas Kesehatan Kabupaten Bandung. Https://Www. Bandungkab.Go.Id/. https://www. bandungkab.go.id/uploads/LAPTAH 2014 GABUNGAN.pdf

Ditjen Bina Gizi dan KIA Kementrian Kesehatan. (2015). Laporan Kinerja Ditjen Bina Gizi dan KIA Tahun 2015. https://kesmas. kemkes.go.id/konten/133/0/020207- 
laporan-akuntabilitas-kinerja-lakipditjen-bina-gizi-dan-kia-tahun-2015

Fuada, N., \& Setyawati, B. (2015). Pelaksanaan kelas ibu hamil di Indonesia. Indonesian Journal of Reproductive Health, 6(2), $67-75$.

Handayani, S. L., Putri, S. T., \& Soemantri, B. (n.d.). Gambaran Dukungan Suami Dalam Pemberian ASI Eksklusif. Jurnal Pendidikan Keperawatan Indonesia, 1(2), 116-124.

Hartatik. (2012). Tingkat Pengetahuan Ibu Hamil Tentang Inisiasi Menyusu Dini Di Bps Dyah Sumarmo Desa Tanjungsari Kecamatan Banyudono Kabupaten Boyolali. Digilib Ukh. https://digilib.ukh. ac.id/files/disk1/1/01-gdl-hartatikb0-291-kti_hart-i.pdf

Kaneko, A., Kaneita, Y., Yokoyama, E., Miyake, T., Harano, S., Suzuki, K., Ibuka, E., Tsutsui, T., Yamamoto, Y., \& Ohida, T. (2006). Factors associated with exclusive breast-feeding in Japan: for activities to support child-rearing with breast-feeding. Journal of Epidemiology, 16(2), 57-63.

Lawrence, G. (1980). Health Education A Diagnosis Approach. The John Hopkins University Mayfield Publishing Co.

Pemkab Bandung. (2016). Laporan Kinerja Instansi Pemerintah Dinas Kesehatan Tahun 2016. Bandungkab.Go.Id. https://www.bandungkab.go.id/ uploads/20180115035259-1kip-2016revisi-terbaru-.pdf

Permadi, M. R., Hanim, D., Kusnandar, K., \& Indarto, D. (2017). Risiko Inisiasi
Menyusu Dini dan Praktek Asi Eksklusif terhadap Kejadian Stunting pada Anak 6-24 Bulan (Early Breastfeeding Initiation And Exclusive Breastfeeding AS Risk Factors Of Stunting Children 6-24 Months-old). Nutrition and Food Research, 39(1), 9-14.

PPRI. (2012). Peraturan Pemerintah Republik Indonesia nomor 33 tahun 2012 tentang pemberian air susu ibu eksklusif. Lembaran Negara RI Tahun, 58.

Rahardjo, S. (2006). Faktor-faktor yang Berhubungan dengan Pemberian ASI satu jam pertama setelah melahirkan. Kesmas: Jurnal Kesehatan Masyarakat Nasional (National Public Health Journal), 1(1), 11-17.

Riskesdas. (2013). Badan penelitian dan pengembangan kesehatan. In Riset kesehatan dasar. http://www.depkes. go.id/resources/download/general/Hasil Riskesdas 2013.pdf

Smith, E. R., Hurt, L., Chowdhury, R., Sinha, B., Fawzi, W., Edmond, K. M., \& Group, N. S. (2017). Delayed breastfeeding initiation and infant survival: a systematic review and meta-analysis. PloS One, 12(7), e0180722.

Sutomo, B., \& yanti Anggraini, D. (2010). Menu Sehat Alami Untuk Batita \& Balita. DeMedia.

Utami, R. (2008). Inisiasi menyusu dini plus ASI eksklusif. Jakarta: Pustaka Bunda, 2-31.

Utami, Y., \& Westri, A. (2016). Peran Kelas Ibu Hamil Dalam Keberhasilan ASI Eksklusif. Jurnal Kebidanan, 6. 